\title{
Development and testing of a community flood resilience measurement tool
}

\author{
Adriana Keating ${ }^{1}$, Karen Campbell ${ }^{2}$, Michael Szoenyi $^{3}$, Colin McQuistan $^{4}$, David Nash $^{3}$, and Meinrad Burer $^{5}$ \\ ${ }^{1}$ International Institute for Applied Systems Analysis, 2361 Laxenburg, Austria \\ ${ }^{2}$ University of Pennsylvania, Wharton Center for Risk and Decision Processes, Philadelphia, USA \\ ${ }^{3}$ Zurich Insurance Group, Zurich, 8002 Zurich, Switzerland \\ ${ }^{4}$ Practical Action, Climate Change and Disaster Risk Reduction, Rugby, UK \\ ${ }^{5}$ International Federation of Red Cross and Red Crescent Societies, Geneva, Switzerland \\ Correspondence to: Adriana Keating (keatinga@iiasa.ac.at)
}

Received: 24 May 2016 - Published in Nat. Hazards Earth Syst. Sci. Discuss.: 31 May 2016

Revised: 8 December 2016 - Accepted: 19 December 2016 - Published: 26 January 2017

\begin{abstract}
Given the increased attention on resilience strengthening in international humanitarian and development work, there is a growing need to invest in its measurement and the overall accountability of "resilience strengthening" initiatives. The purpose of this article is to present our framework and tool for measuring community-level resilience to flooding and generating empirical evidence and to share our experience in the application of the resilience concept. At the time of writing the tool is being tested in 75 communities across eight countries. Currently 88 potential sources of resilience are measured at the baseline (initial state) and end line (final state) approximately 2 years later. If a flood occurs in the community during the study period, resilience outcome measures are recorded. By comparing pre-flood characteristics to post-flood outcomes, we aim to empirically verify sources of resilience, something which has never been done in this field. There is an urgent need for the continued development of theoretically anchored, empirically verified, and practically applicable disaster resilience measurement frameworks and tools so that the field may (a) deepen understanding of the key components of "disaster resilience" in order to better target resilience-enhancing initiatives, and (b) enhance our ability to benchmark and measure disaster resilience over time, and (c) compare how resilience changes as a result of different capacities, actions and hazards.
\end{abstract}

\section{Introduction}

The Hyogo Framework for Action, established 10 years ago, set out an ambitious framework for addressing disaster risk. While the platform was successful in reducing disaster mortality globally, there has not been similar success in tackling the underlying factors driving increasing exposure of people and assets to hazards (UNISDR, 2013, 2015). This is a goal of the subsequent Sendai Framework (2015-2030) and arguably requires a collaboration and integration between the disaster risk management (DRM) field and wider investment and development planning, in particular within the international development sector (Schipper and Pelling, 2006). At the same time, the cost effectiveness of ex ante risk reduction over ex post response is increasingly recognized (Mechler, 2016) and is increasingly relevant under conditions of funding scarcity (Frankenberger et al., 2014). Disaster resilience has come to the fore as an integrating concept by assisting in identifying novel ex ante strategies for integrated approaches to disaster risk reduction and response, as well as sustainable development. Disaster resilience definitions, frameworks, and approaches are being developed and promoted prolifically (Frankenberger et al., 2014; Winderl, 2014; Mitchell, 2013).

While resilience theories have informed wide-ranging disciplines for quite some time, an effort to identify operational indicators has gained some traction only in the last decade (Carpenter et al., 2005). Given the increased attention on enhancing disaster resilience, there has been growing investment in its measurement and the overall account- 
ability of "resilience strengthening" initiatives. As identified by National Academies of Sciences (NRC, 2012) and Levine (2014) among many others, there is an urgent need for the continued development of theoretically anchored and practically applicable disaster resilience measurement frameworks and tools so that the field may (a) deepen understanding of the key components of "disaster resilience", (b) enhance our ability to benchmark and measure disaster resilience over time, and (c) compare how resilience changes as a result of different capacities, actions, interventions, and hazard events.

The primary purpose of this paper is to present the Zurich Alliance community flood resilience measurement framework and associated tool, developed by an alliance of NGOs, academic institutions, and the private sector ${ }^{1}$. Each member brought a unique perspective and experience on the theoretical and practical considerations for designing and using a community flood resilience measurement framework and tool. At the time of writing the tool has undergone baseline implementation in 75 communities worldwide. The unique contribution of this framework and approach is that it is building a standardized database of pre-event characteristics and post-event outcomes, which will then be explored to generate evidence empirical evidence for resilience-building initiatives (discussed below). We trace the process of framework and tool development and rollout, outlining key successes as well as challenges. We note that this paper is not designed to build theory but rather to offer a practical application of theory. As a secondary purpose of this paper, we believe that by sharing our process others, such as researchers, policymakers, and practitioners, entering the fledging field of resilience measurement may learn from our experience.

Before delving into resilience measurement, we must first identify what it is we are attempting to measure; for disaster resilience this is not straightforward. "Resilience" has a long history, being adopted in different disciplines including engineering, psychology, ecological systems theory, and economics. In the disasters field, the central interest of this paper, resilience has a long and multidisciplinary history (for a review see Zhou et al., 2010). As the concept took hold in the disaster literature and practice, efforts to define it became a priority. Currently there exists a plethora of definitions of "disaster resilience" (see for example Adger et al., 2005; NRC, 2012; ABD, 2013; DFID, 2011; IPCC, 2012; Twigg, 2009). The field is characterized by lack of conceptual clarity and considerable debate (Zhou et al., 2010).

\footnotetext{
${ }^{1}$ The alliance members who designed and are managing the implementation of the tool are the International Federation of Red Cross and Red Crescent Societies (IFRC), the International Institute for Applied Systems Analysis (IIASA), the Wharton Business School's Risk Management and Decision Processes Center (Wharton), the international development non-governmental organization Practical Action, and Zurich Insurance Group who are also funding the endeavour.
}

A central critique of resilience thinking is that it is a normative approach that accepts the system(s) as a given and works within it, crowding out space for questioning the underlying problems. Berkes and Ross (2013) identify lack of attention to power and agency as key critiques of resilience in DRM. That is, by focusing on existing community capacities, resilience thinking might miss important institutional arrangements that are limiting community capacity. Further to this is the critique that resilience is attractive to the "small government" discourse and is being used to justify shifting risk from government onto citizens (Welsh, 2013). Our approach to resilience, outlined below, starts with the current system before connecting with development and vulnerability theory to put people at the centre of decisions regarding their risk and wellbeing.

One of the early tasks of the alliance was to identify the research gaps in community flood resilience. As part of this research we conducted a review of resilience definitions, which is summarized in Keating et al. (2014, 2017). We then came to our definition of disaster resilience which underlies the measurement framework: the ability of a system, community, or society to pursue its social, ecological, and economic development and growth objectives, while managing its disaster risk over time in a mutually reinforcing way. Central to this conceptualization are the key community capitals - social, human, physical, financial, and natural - which holistically make up the socio-economic system (DFID, 1999; Keating et al., 2014, 2017). This conceptualization is centred on enhancing wellbeing as the goal of resilience, rather than disaster risk management, which can be a means to resilience. This puts focus on the interplay between disaster risk management and development trajectories, such that if one undermines the other then disaster resilience is not achieved. A key example of undesirable interplay is that of erosive coping - where actions taken to respond and recover from floods erode long-term wellbeing, potentially even trapping people in a poverty cycle (Heltberg et al., 2012). Alternatively, actions which are designed to enhance wellbeing, but lead to an unbalanced increase in disaster risk, are also undesirable.

Reviews and analyses of the state-of-the-art of disaster resilience measurement (Schipper and Langston, 2015; Winderl, 2014; Levine, 2014; Mitchell, 2013; Constas and Barrett, 2013) catalogue a plethora of offerings focused from the household to the national scale, from single hazards to multiple hazards to general resilience, and designed for different purposes. We, along with many others (Schipper and Langston, 2015; Levine, 2014), emphasize that there is no one-size-fits-all "resilience" measure, nor should there be. The development of various and varied resilience measurement frameworks should be seen as a positive step towards understanding resilience and operationalizing the concept. At the same time, many scholars and practitioners would like to know if there are any widely applicable capacities which pro- 
vide for disaster resilience or if they are solely contextually and temporally specific.

Empirical evidence for the existence of such capacities is a critical gap in the field. Despite the proliferation of frameworks, Winderl's (2014) review concurs with many others that "no general measurement framework for disaster resilience has been empirically verified yet" (p. 19). This highlights a key challenge for any resilience-building efforts: if resilience cannot be empirically verified, how can we know we are measuring actual resilience? When most discuss "measuring resilience" they are really aiming to measure resilient capacity before an event. Stakeholders need to know before a risk event occurs whether they have effectively balanced risk and opportunity in building capacity to withstand and recover from the event. Related to this is the fact that civil groups, authorities, and NGOs would like to know whether activities they have implemented with the purpose of building resilience have achieved their goal. Winderl (2014) outlines the problem of circular reasoning when it comes to measuring ex ante: if we determine a priori which characteristics make a system resilient, then design interventions to enhance these, then measure again - we will necessarily find that resilience has been increased. However, with no empirical evidence to justify the selection of those characteristics in the first instance, we have no real evidence that resilience has actually been increased. As a latent property disaster resilience is only visible, or "revealed", after a disaster has occurred (Schipper and Langston, 2015; Frankenberger et al., 2014), yet measuring impacts or outcomes in isolation tells us very little of what contributed to actual resilience. This is a critical distinction which is not always fully acknowledged in disaster resilience definitions and measurement frameworks.

However, this is precisely the distinction that is critical for empirically testing resilience measures. That is, to empirically test and validate a measure of resilience, it is required that (a) implementation of the measurement occurs across different contexts and is monitored consistently over time and (b) understanding and capturing both pre-event characteristics (what we call sources of resilience) and a set of pre-determined post-shock outcome measures occur, in order to learn which sources are most effective for the realization of resilient outcomes. We know of no disaster resilience measurement frameworks or programs which do this. It is this gap that the Zurich Alliance community flood resilience measurement framework and associated tool presented below aims to fill in the context of community flood resilience. The content of our measurement framework has been drawn from the existing literature (providing theory and evidence) and alliance members and peer group expertise. It is an indicator-based approach consisting of 88 measures of potential sources of resilience (listed in Appendix B) and 29 postflood outcome measures (also listed in Appendix B). At the time of writing the tool is being tested by six NGOs, in approximately 75 communities across eight country programs.
The initial programme will allow for preliminary empirical testing and feedback from implementers.

The paper proceeds as follows: first we review current thinking on measuring resilience and draw out pertinent challenges, particularly relating to empirical validation. We then describe the measurement framework development process. Next we present the content of the framework and then describe the operationalized tool. In the conclusion we present our path forward for undertaking much needed empirical analysis to understand community flood resilience. By documenting our process, we hope that others looking to measure resilience, or develop a resilience measurement framework of their own, can learn from our experience.

\section{Review: the challenge of measuring resilience}

Several national and international aid agencies have proposed versions of resilience indicators (Alinovi et al., 2009; USAID, 2013) and a number of regional disaster resilience indicators have also been developed (Cutter et al., 2010; Resilience Capacity Index, 2017). Twigg's (2009) Characteristics of Disaster Resilience Community is designed for, and in cooperation with, NGO and civil society organizations; it systematically and extensively explores many factors which may contribute to disaster resilience. More recently the BRACED project has proposed a composite index to measure resilience based around tracking adaptation, anticipation, absorption, and transformation (Bahadur et al., 2015).

The last few years have seen a number of reviews of disaster resilience measurement frameworks (Schipper and Langston, 2015; Winderl, 2014; Ostadtaghizadeh et al, 2015; Oddsdottir et al., 2013). Schipper and Langston (2015) review 17 sets of indicators from the household to the national level. We do not aim to reproduce such a review here, but instead draw on these and other critical analyses to highlight some of the challenges associated with measuring disaster resilience. There are many substantial differences between national versus local-level disaster resilience and associated measurement frameworks. Because the framework presented here is at the community level, our review focuses on issues and challenges at this scale. There are few examples of comprehensive community disaster resilience measurement frameworks available, only a handful of which have been implemented in the field and none that are empirically validated (Winderl, 2014); this is because measuring resilience is not straightforward for two main reasons: (1) it is a latent quality that is not revealed until tested and (2) the characteristics that influence this latent quality are often a complex set of holistic and qualitative characteristics.

Measuring latent and qualitative characteristics is not a challenge unique to resilience measurement. Gathering and synthesizing subjective (opinion) and/or qualitative (narrative) information is a mainstay of modern development mon- 
itoring and evaluation (M \& E) practice. The Resilience Measurement Technical Working Group has undertaken a comprehensive review of, and developed a position on, qualitative data and subjective indicators for resilience measurement (Constas et al., 2015). They find that qualitative and subjective measures are essential to resilience analysis, particularly in relation to social factors. They suggest mixed methods approaches and that solid planning (including resourcing) are required to undertake effective qualitative data collection. Below we describe how our framework and tool tackles this challenge.

Thus community disaster resilience measurement frameworks or indicators - including ours - share many common theoretical and practical challenges. First, in doing this work, initial questions immediately confronted are (1) defining an appropriate scale of analysis both geographically and temporally - specifying boundaries such as "resilience of what to what?" (Carpenter et al., 2001) - and (2) identifying the potential end users ("indicators for whom?") and potential purposes ("indicators for what?"). This helps bring clarity into the complex process of measurement framework development (de Sherbinin et al., 2013). Without these specifics it becomes increasingly difficult to distinguish disaster resilience measurement frameworks from general development assessments. A key challenge, however, is balancing the need for specific indicators (to a particular hazard in a particular place for a particular institution) and the need for wide applicability. A related further challenge is that resilience to one hazard does not necessarily translate into resilience to another. In fact, it is entirely possible that measuring and enhancing resilience to one hazard may inadvertently reduce resilience to another (Schipper and Langston, 2015).

Particularly pertinent to our community-level framework is the observation by several authors (Béné et al., 2012; Frankenberger et al., 2014) that resilience at the community level is dependent upon changes at lower "levels", i.e. individuals and groups within communities, as well as changes at higher municipality, national, or even global levels, which are outside the scope of direct NGO community programming initiatives. NGOs are often limited in their capacity to activate change at these scales. "Community" itself is a particularly elusive concept without clear definition. It is a highly contested term and has been critiqued from multiple perspectives. Particularly relevant to disaster resilience is the inherent tension between discourses of empowerment, which dominate the rhetoric, which have "concealed a much more conformist and conservative reality" (Shaw, 2007, p. 26) borne of the paternalistic history of the development field. Our definition of community is outlined in Sect. 3.

As communities are dynamic complex systems, Levine (2014) argues that the modular approach to measuring resilience, such as measuring a set of discrete characteristics, "assumes that improvements in any component of resilience score are of equal importance" (p. 8). As he suggests, this is deeply problematic when thresholds are present: an increased score in some areas might not actually afford a benefit until it reaches a certain threshold or unless it is combined with some other characteristic or capacity. A further challenge is that resilience can change over time depending on changes both within and outside the system (Holling, 2001). The extremely scale-, place-, and system-specific nature of capacity profiles also creates difficulties when attempting to generalize a set of key factors which enhance resilience (Tol and Yohe, 2007; Vincent, 2007).

Lastly, Béné et al. (2012) and Levine (2014) put forward the critique that a resilience-focused perspective runs the risk of diverting attention away from the most vulnerable or marginalized groups in a community, in favour of a more average community-wide perspective. We must be cognizant of the fact that building the resilience of the majority does not necessarily meet the development needs of the poorest. Resilience is not a pro-poor concept, in that it does not exclusively apply to, or benefit, the poor. As such, resilience building does not replace poverty reduction (Béné et al., 2012) but can rather be considered as one element in protecting current and future development gains.

\section{Method: development of the measurement framework}

The Zurich Alliance community flood resilience measurement framework has been pilot tested, reviewed, and revised, and now a beta version has been adapted into a web-based platform and integrated mobile data collection application, via which implementers collect data and assign grades for each of the indicators (pre-event "sources of resilience" and post-event impact assessment).

The conceptualization of disaster resilience underlying the framework is set out in the introduction. Narrowing this down, for the purposes of this framework we are specifically interested in the resilience of communities to flooding. While acknowledging that national and global drivers play a significant part in flood resilience, the community level is where flood impacts are felt most viscerally, where much action on flood resilience needs to be taken and are the focus of many flood and development activities. The NGO practitioners on the design team put forward the definition of community used here. A "community" could be defined geographically (perhaps in rural contexts) or by administrative boundaries (which may work in more urban situations). However, no single community will "feel" like another and there are cultural aspects to consider, too. As a result we have concluded that when it comes to ground reality a community largely defines itself. 


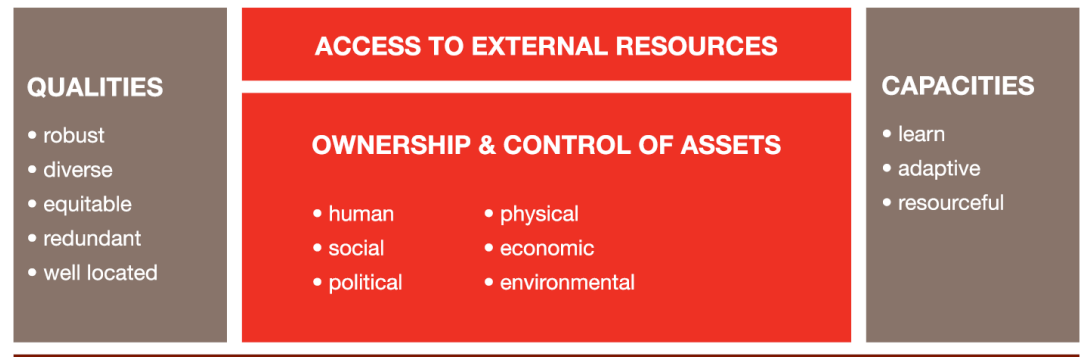

MEETING BASIC NEEDS

Figure 1. Conceptual framework of community resilience (source: IFRC, 2012).

\subsection{Foundations of the measurement framework}

The measurement framework was conceived by integrating the underlying disaster resilience perspectives and frameworks of the alliance members. Constas et al. (2014) identify resilience as a "multidimensional capacity" and while their suggested dimensions differ slightly from the ones presented here, we are in full agreement that community flood resilience is about the combination of capacities across different dimensions. Following the focus on overall wellbeing and development as the overarching goal of disaster resilience in our definition, the sustainable livelihoods (SL) framework (DFID, 1999) was drawn upon to capture community assets and capacities. The SL framework is an assetbased framework, representing the core capacities (or asset base) that enables the overall community system to provide wellbeing, opportunity, and risk management. From a practical perspective, it has been widely used in community development as a conceptual device (Knutsson and Ostwalk, 2006) and as such is well understood within the community development field. It is applicable for developing and developed countries, at multiple scales, qualitatively and quantitatively ${ }^{2}$.

However, capital levels and combinations in and of themselves do not tell us explicitly how well a community may perform in the face of the uncertain risks and opportunities. This led to the question of whether we could identify some general properties or principles to look for in communities that are thought to enhance resilience over time and in various contexts. This led to consideration of the four "resilience properties" (4Rs) defined by MCEER (Bruneau, 2006; Cimellaro et al., 2010): redundancy, resourcefulness, rapidity, and robustness (defined below).

The next step was to make this conceptual framework operational. For this we first drew on the practical and programmatically focused expertise of our NGOs and risk engineers within the measurement framework design team. In particular, the IFRC's (2012) framework depicted in Fig. 1 was

\footnotetext{
${ }^{2}$ These points were articulated by participants at our peer review of the framework held on 29 June-1 July 2015.
}

drawn on in the development phase of the framework. Of particular influence here was the that this framework (and our's) places people and their agency at the literal centre of thinking on disaster resilience. The "qualities" listed in the panel on the left were used to cross-check indicator grade definitions, especially in relation to equity. The top panel on external resources informed the framework to separate out "community-level" indicators and "enabling condition" indicators.

Also informing our thinking was Practical Action's (Pasteur, 2011) Vulnerability to Resilience (V2R) framework (Fig. 2). This is an analytical approach that can be used at community level to combine current and future risks with the capacities and assets that the community have available to drive their development. Sections of this framework directly informed indicator development: bullet points in the cycle were expanded and further specified so that each step in the cycle is captured in our framework.

The NGOs assessments and data gathering processes used to inform their work within these frameworks were emulated to assess the sources of resilience (for example focus groups and household surveys). Secondly, our measurement approach is, uniquely, informed by risk engineering expertise, in this case from Zurich Insurance. Risk engineering is a technical assessment approach to identify, assess and improve risk to specific perils. Risk engineering often works with technical risk grading standards (TRGSs), technical documents which offer a standardized view of risk and highlight priority actions that could be taken to reduce risks. TRGSs are tailored to different perils, taking account of the different factors that make up risk associated with that peril. Each TRGS includes risk factors (indicators) and defines the evidence needed to earn that factor a grade of A, B, C, or D. Grades are assigned as follows:

1. A for best practice for managing the risk;

2. B for good industry standard, with no immediate need for improvement;

3. C for deficiencies, with room for visible improvement; 


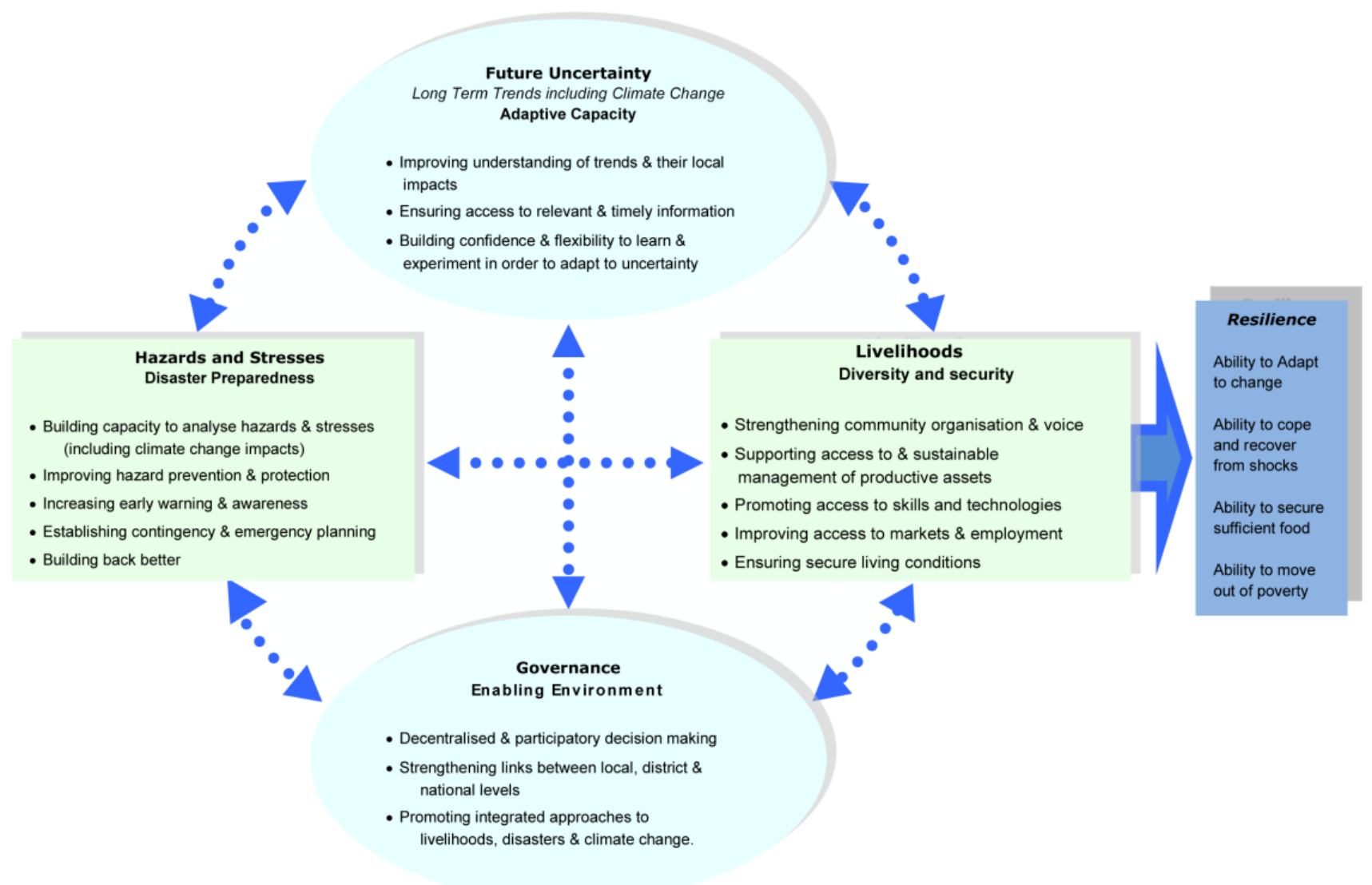

Figure 2. Vulnerability to Resilience framework (source: Pasteur, 2011).

4. D for significantly below good standard, with potential for imminent loss.

Engineers compare data, often gathered from locationspecific site visits, with the definitions in the TRGSs to make a judgment on risk quality and conduct conversations with the site or company about how to manage the risks they are facing. Clearly, a community is profoundly different from a firm. Similarly, risk is not the same as (or the inverse of) resilience. The insight drawn from the risk engineering approach for the community flood resilience measurement framework was regarding the utility and benefits of having a trained assessor make a qualified judgment to assign a grade of A to D for each of the different factors. We discuss the benefits of this approach below.

\subsection{Measurement framework content development}

The SL 5C framework provides a holistic perspective of wellbeing, as well as community assets and capacities. The IFRC (2012) and Pasteur (2011) frameworks provide a highly generalized approach to features for improving disaster resilience, while the 4Rs inform the quality of the community characteristics (which became known as sources of re- silience). However, as we review above, much work has been done to establish specific measures of disaster resilience. Our measurement framework drew on the insights from this body of work via a comprehensive review of what sources of resilience have been qualitatively shown or are widely considered to be important for community-level resilience to flooding. The articles and reports which finally contributed most substantially to the content of the measurement framework are (in alphabetical order) Bahadur et al. (2015), Cutter et al. (2010), DFID (2009, 2011), IFRC (2011, 2014), MCEER (2007), NRC (2012), OECD (2014), Oxfam GB (2013), Pasteur (2011), and Twigg (2009). A further 46 documents were reviewed and informed the content of the framework; these are listed in Appendix A. It should be noted that the development, testing, and reviewing process that the framework has gone through has seen it evolve substantially, and it would no longer be possible to assign citations to specific sources of resilience.

The first version of the measurement framework - Version 1 - was piloted in 24 communities in Mexico, Nepal, and Peru. This pilot testing was undertaken by the design team in collaboration with NGO staff familiar with the communities being assessed. The framework was then revised in response 
to the lessons learned from this testing. One of the first lessons learned was that effective use of such a framework requires that all sources be discrete concepts, since multiple parts within each source often resulted in an average, and hence meaningless, grade. Furthermore, some sources were assigned an interdependency condition; i.e. they cannot be graded above a certain threshold unless a certain grade is attained or exceeded on another, interdependent, source (interdependency is a point highlighted by Levine, 2014).

Version 1 of the measurement tool was dominated by disaster preparedness and response capacities, as opposed to risk reduction and more systemic development considerations. We consider that this was due to a number of factors, including because they (a) continue to dominate the disasters field, (b) are front and centre of other disaster resilience measurement frameworks, and (c) are relatively easy to measure. By reflecting on our definition of disaster resilience, we saw the need to balance preparedness and response with other important elements of disaster resilience. Many of the sources now are concerned with the capacity of households and the community to consider disaster risk in their broader planning and to take action to reduce risk rather than just prepare for it.

Version 2 of the measurement framework was developed by the design team in response to lessons learned from the pilot testing. This version saw each source also assigned a number of qualities or categorizations in addition to the 5C-4Rs; these are presented below. A peer-review workshop was then convened with 10 preeminent disaster resilience and measurement experts. The workshop led to a number of changes to Version 3 of the framework and also crystallized a number of issues regarding usage and feeding back information to communities. The importance of power dynamics in social capital sources was emphasized, expanding the social capital section to include what might be termed "institutional" or "political" capital. The review also underlined the challenge of providing suitable flexibility in how the tool could be applied to enable it to be appropriate to context, while still maintaining enough standardization to generate comparable data. The testing version of the tool is such that each source is graded to produce standardized data (A-D grading), yet is sufficiently general to apply across contexts; implementers are able to choose one or more data sources as they see fit, from at least two and up to five options, each with associated indicators for each source.

\section{The community flood resilience measurement framework}

This measurement framework applies specifically to community-level resilience to flooding and is designed to (a) help guide NGO community development and floodbased programs and (b) to provide a platform for empirical analysis of resilience. As Frankenberger and Nelson (2013) point out, an approach to resilience measurement which measures ex ante but does not test whether what was measured was relevant once the event occurred cannot make any claims about having measured resilience. By tracking the sources of resilience both pre- and post-event, together with outcomes in the event of a flood, we can observe how development, disasters, and DRM activities occurring in the community are eroding or supporting wellbeing. Over time and studies in different contexts, this testing can build an evidence base for what actually makes the difference for community-level resilience to flooding.

The 88 sources of resilience have been developed with the underlying frameworks of the five capitals (5Cs) and the 4Rs. These were then cross checked by categorizing them within three other operational frameworks commonly used by NGOs. These provide a cross check not only that we are measuring a holistic set of sources but also that the suite of categorizations attached to each source provide for analytical depth by allowing for multiple perspectives on the results. These also increase the ability to communicate results to many different stakeholder audiences in the contexts within which they are working. We provide examples of each of these categorizations below.

Before exploring dimensions of the tool in detail, we provide Fig. 3 as a reference point. The figure shows the steps that are undertaken when using the framework and where different aspects fit. The first step is data collection (see Sect. 4.3), which can be done using various methods. After data have been collected, experts assign grades to each of the 88 sources of resilience, according to the source rationale and the A-D grade definitions. Each source has already been assigned (tagged) to the five categorizations (Sects. 4.1.1 to 4.1.5). Once all 88 sources are graded, results are generated according to the different categorizations.

\subsection{How sources are organized within the framework}

The 88 sources of resilience are each categorized by the $5 \mathrm{Cs}$, by the 4 Rs, by 10 themes, by the two perspectives of the system level (community and enabling environment), and by the five phases of the DRM cycle (Appendix B lists sources with associated categorizations).

\subsubsection{Five capitals}

The most prominent categorization of the sources of resilience is along the 5Cs of the SL framework. This framing was an inherent part of the measurement framework from inception, and strongly emphasizes the multidimensional nature of resilience. For example, it is not enough to have a school facility which is robust and accessible in times of flooding (physical capital) - a community also needs a strategy to maintain or quickly resume schooling in the event of a flood (social capital) and an intrinsic value placed on education by parents (human capital). We follow the definition 


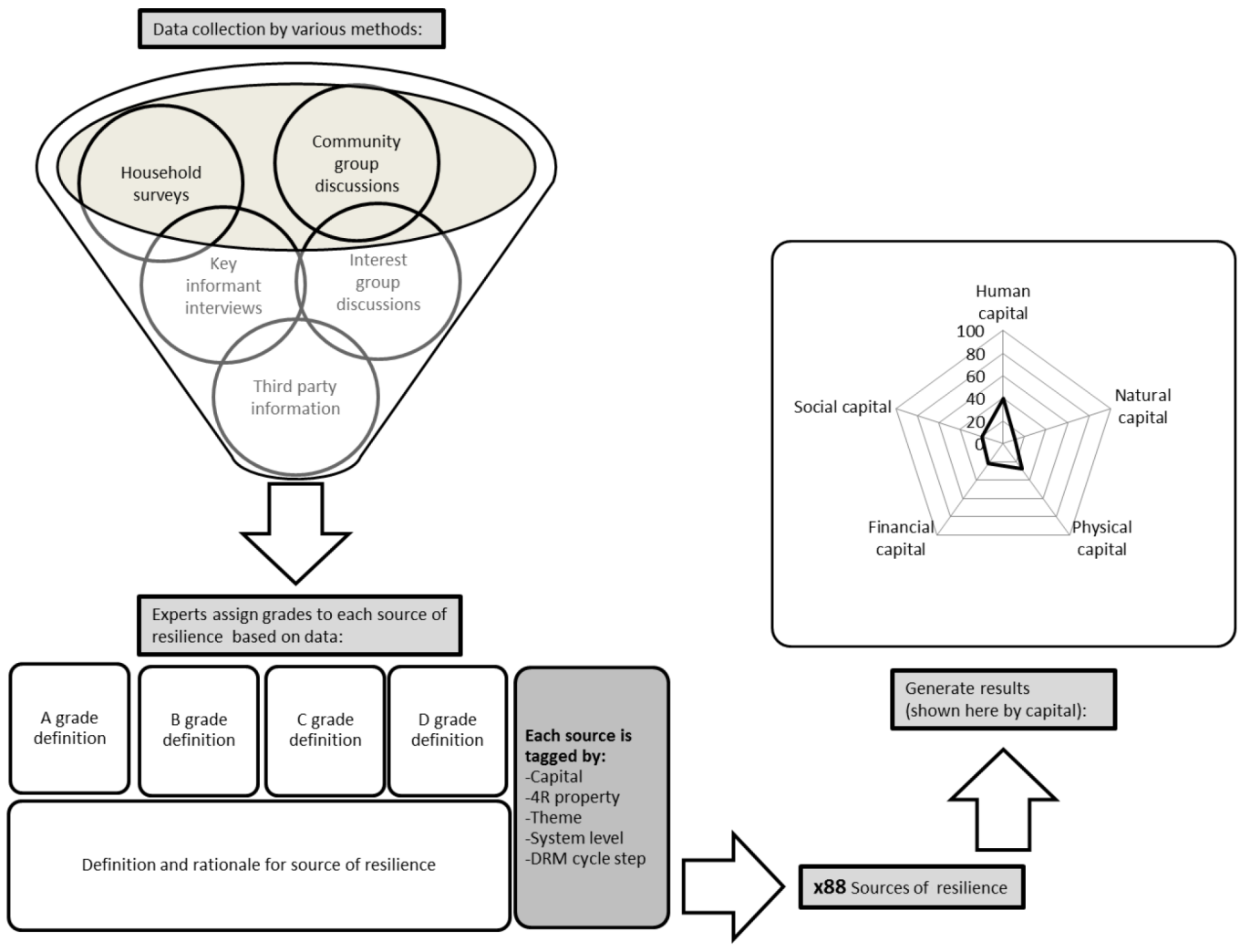

Figure 3. Zurich Flood Resilience Measurement Framework implementation process.

of the five capitals by Nelson et al. (2007) and provide an example source within each capital group.

- Human capital is the education, skills, and health of household members. The source of resilience "flood protective behaviour and knowledge" assesses people's knowledge/skills about how to behave during a flood event, in order to prevent death and injury.

- Social capital is the reciprocal claims on others by virtue of social relationships and networks, the close social bonds that aid cooperative action and the social bridging, and linking via which ideas and resources are accessed. The source of resilience "community representative bodies/structures for flood management coordination" assesses the degree of formal organization of the community as a whole around flood risk management.

- Natural capital is the natural resource base, e.g. productivity of land, and actions to sustain productivity, as well as the water and biological resources from which livelihoods are derived. The source of resilience "basin health" assesses how changes in natural habitats are exacerbating or reducing the flood risk in the target community.

- Physical capital is capital items produced by economic activity from other types of capital that can include in- frastructure, equipment, and improvements in genetic resources, e.g. crops, livestock. The source of resilience "access to health care facilities" assesses the adequacy of the infrastructure to support community health and how it stands up in flood situations.

- Financial capital is the level, variability, and diversity of income sources and access to other financial resources (credit, savings, cattle) that together contribute to wealth (Nelson et al., 2007). The source of resilience "household financial savings that protect long-term assets" assesses the availability of liquid assets to cover expected flood losses.

\subsubsection{Four properties of a resilient system}

The 4Rs help to evaluate where there may be weaknesses to one or more of these four areas and thus where the communities' systems may be vulnerable should a disaster event occur. We hypothesize that the 4Rs may be able to shed light on why some communities fare better than others in the same disaster, despite identical capital endowments. An examination of the financial capital profiles of the two communities might reveal that Community A has a diversified income base whereas Community B is dependent on a single industry. This redundancy has been demonstrated to be a source of quicker recovery after a disaster. The $4 \mathrm{Rs}$ are defined below 
(Bruneau, 2006; Cimellaro et al., 2010), each with an example source.

- Redundancy is the extent to which alternative elements, systems, or other measures exist that are substitutable, i.e. capable of satisfying functional requirements in the event of disruption, degradation, or loss of functionality. Household credit access (financial capital) assesses the availability of credit (both formal and informal) for members of the community during and directly following a flood.

- Resourcefulness is the capacity to identify problems, establish priorities, and mobilize alternative external resources when conditions exist that threaten to disrupt some element, system, or other measure. Resourcefulness can be further conceptualized as consisting of the ability to apply material (i.e. monetary, physical, technological, and informational) and human resources in the process of recovery to meet established priorities and achieve goals. Educational attainment (human capital) assesses the level of education attained by individuals and households in the community.

- Rapidity is the capacity to meet priorities and achieve goals in a timely manner in order to contain losses, recover functionality, and avoid future disruption. Rapidity takes account of learning and recovering in a more resilient way, which may involve a transformation. While it is mostly an ex post property of resilience, investments made ex ante can create rapidity ex post. Strategy to maintain or quickly resume provision of local food supplies in the event of a flood (social capital) assesses the existence or not of a plan (including standardized operating procedures) to maintain or quickly resume flood supply systems in the event of a flood, and evaluates to what degree it is up to date, as well as whether it is certified against national standards.

- Robustness is strength, or the ability of elements, systems, and other measures of analysis to withstand a given level of stress or demand, without suffering degradation or loss of function. Communal flood protection (physical capital) assesses the adequacy of large-scale flood protection measures which protect the whole community from flood.

\subsubsection{Themes}

The realities of community development work called for more tangible categorizations. As such, we have also taken a sectoral view where critical aspects of community life are explored in a way meaningful for NGO practitioners. The themes cut across the 5Cs and in many ways link them up. The themes are

- life and health

$$
\begin{aligned}
& \text { - education } \\
& \text { - assets and livelihoods } \\
& \text { - food } \\
& \text { - transport and communication } \\
& \text { - water } \\
& \text { - waste } \\
& \text { - energy } \\
& \text { - governance } \\
& \text { - natural environment. }
\end{aligned}
$$

The themes also helped define the outcome indicators, discussed below.

\subsubsection{System level}

Our measurement framework is concerned specifically with actions at the community level, but what happens at the community level is dependent upon systems at both lower and higher levels (Keating et al., 2017; Constas et al., 2014). At the same time, there exist practical constraints on data collection. In response to this tension, we have focused the tool on the community level, while including a number of "enabling environment" sources of resilience which were considered critical for the analysis. Social inclusiveness, from the social capital group, is an example of a community-level source; social safety nets (legislative, national schemes) are an example of a source from the financial capital group at the enabling environment level. Enabling environment sources are understood to be outside the direct sphere of influence of the community, although may be the target of higher-level advocacy.

\subsubsection{DRM cycle}

The DRM cycle is a well-known concept in the disasters field. Following the UNISDR (2009), DRM is the "systematic process of using administrative directives, organizations, and operational skills and capacities to implement strategies, policies and improved coping capacities in order to lessen the adverse impacts of hazards and the possibility of disaster. Disaster risk management aims to avoid, lessen or transfer the adverse effects of hazards through activities and measures for prevention, mitigation and preparedness". While we conceptualize disaster resilience to go beyond traditional DRM, the fields are clearly interconnected.

Categorizing each source of resilience by which stage of the DRM cycle it aligns most closely to is also critical for exploring whether action to manage disaster risk is focused unevenly at some point of the DRM cycle. A common issue facing DRM and disaster resilience more broadly is a focus 
on ex post crisis response and a neglect of ex ante risk reduction (Kellet and Caravani, 2013). The reasons for this are many and complex; the purpose here is to shine a light on strengths and weaknesses at the community level. Within the framework we define four stages of the DRM cycle and provide an example source for each:

- Prospective risk reduction are activities that address and seek to avoid the development of new or increased disaster risks. For example, flood exposure perception (human capital) assesses the accuracy of community perception/expectation of flood inundation areas.

- Corrective risk reduction are activities that address and seek to correct or reduce disaster risks which are already present. For example, sustainable use of natural resources (natural capital) assesses whether livelihood activities impact on natural capital are managed to minimize their negative impact on these habitats.

- Crisis preparedness is action carried out before an event to build capacities needed to effectively manage the flood emergency situation and achieve orderly transitions from response to recovery and reconstruction. For example, measurement and forecasting (physical capital) assess the quality of locally accessible flood forecasting network.

- Coping is the ability of a community to utilize available skills and resources to manage the adverse conditions brought on by the flood. For example, business credit access (financial capital) assesses the availability of credit (both formal and semi-formal, and can include vendor credit) for members of the community during and directly following a flood.

The cyclical nature of the DRM cycle is a critical feature; the stages of the cycle naturally blend into one another. In particular, the coping and recovery phase following a disaster provides an opportunity for prospective risk reduction in the next cycle. These designations will likely be refined as the analysis proceeds.

\subsection{Post-flood outcome measurement}

Within this framework outcomes refer to the way in which a flood has impacted a community's wellbeing and development potential. We have identified 29 outcome measures to be collected following flood events which may occur in program communities during the testing period. These consist of 19 flood impact measures, seven during-flood "action" measures, and three flood severity control measures (see Appendix B for full list). This information is required to empirically explore the effectiveness of the sources. The measures included here were drawn from the literature review described in Sect. 3.2, During this review process we identified both pre-event characteristics (which informed the sources of resilience) as well as post-event outcomes which informed the outcome measures. We also reviewed standard practice in flood impact assessment in order to identify which flood impacts tend to be most important for communities. Finally, these outcome measures were validated against practitioner experience at two NGO workshops in 2016, where participants were asked to identify the most salient impacts of floods; outputs from this exercise aligned extremely well with the outcome measures in the framework.

Outcomes are built around the 10 themes because this is where they most logically aligned, with at least one outcome variable for each theme. They are also assigned a system level. We provide an example of each type of outcome measure.

- Control variables record the severity and extent of the flooding. These are required so that impacts can be analysed with control for how severe the flood was. For example, flood frequency assesses the return period of the flood event.

- Impact variables record the level of loss or damage of the flood and the time to recover on the different dimensions of community wellbeing. For example, prevalence of post-flood illness assesses the frequency of water and vector born disease in the post-flood period, as compared to normal times.

- Action variables record what actions the community took during and following the flood, which may impact wellbeing. For example, selling assets assesses to what extent both productive and non-productive assets were sold in order to cope with flood impacts.

Our approach aims to collect outcome measurement data within eight weeks of the event. Collecting in the first weeks following an event was considered to be disruptive to relief efforts, yet waiting much longer than this runs the risk of lack of priority and missing critical aspects of a resilient outcome (e.g. recovery time).

\subsection{Data collection methods}

Assessors are provided with multiple options for gathering the data required to grade each sources of resilience and outcome measures. Data to inform grading of many sources of resilience can be collected via any of the available methods. If a data collection method is available for a source, the tool provides pre-defined questions such as a household survey question or a question to ask an expert in an interview. In the set-up phase, assessors select one or several of the data collection methods they intend to use for each source. Each data collection method has strengths and weaknesses; assessors make their selection depending on the local context and appropriateness, the resources available to them to gather the data, availability of existing information, and internal NGO objectives. The five options for data collection are as follows: 
- Household surveys are used to collect data on recipient communities, as is standard practice for many NGO practitioners. In this case the measurement tool web interface automatically loads surveys onto mobile phones, which are then taken to the field by enumerators. Training is provided to implementation teams on appropriate sample size, as well as good best practice sampling techniques.

- Community consultations or community discussions are another mainstay of contemporary development practice, as such practitioners are typically very skilled at setting up and facilitating these processes. There are many existing community consultation processes which data gathering associated with this resilience measurement endeavour can be integrated with, including participatory rural appraisal and vulnerability-capacity assessment.

- Key informant interviews are another important source of information for assessing sources of resilience. In this case practitioners use their local knowledge and contacts to identify people who hold information critical to understanding resilience in the community. For example, they may speak with the local school principal to ascertain the state of flood contingency planning for the local school.

- Interest group discussions are similar to community group discussions in that they are common practice and are run in a similar fashion. Interest groups who might have information pertinent to community flood resilience include, for example, a local weavers group, local small business owners, or the local disaster preparedness committee.

- Third-party sources are secondary (as opposed to primary) sources of information which practitioners can use to gather information on the sources of resilience, which have been produced by a third party. These might include NGO reports, government reports or documentation, newspaper reports, or even census data.

For many sources of resilience more than one data collection option is available, and more than one can be selected when the study is being set up. Preliminary feedback from baseline implementation indicates that while selecting more than one data collection method occasionally results in a contradiction, more often than not it enhances confidence in the final grade assigned.

\subsection{Grading and weighting}

Once all data has been collected, the 88 sources of resilience are individually graded from A to D. Grading is done by a trained assessor drawing on their experience, training, a user manual, and other associated guidance documents. The assessor (or assessment team as is often the case) is presented with the data collected in the data collection phase and considers it in reference to the A-D grade definitions. The benefit of using an A-D grading approach, rather than collecting and trying to "objectively" assess raw data, is that it allows for semi-quantitative assessment of qualitative properties. It also allows for multiple information sources to be considered, and local understanding and context to be incorporated. Finally, it allows assessors to use their expert judgement rather than forcing them to creatively generate data which are unavailable. The grading stage is finalized using a peer-review approach where a colleague assessor sufficiently familiar with the local community context will jointly discuss the grades with the main assessor. Grades will then be finalized and "frozen", i.e. they cannot be further changed, before the results are displayed. This is to avoid "engineering" certain aspects into desired results by changing grades retrospectively.

A fully specified source of resilience, named "access to school facilities" from the physical capital group, is set out in Appendix C.

The output is the list of 88 grades, plus a series of average grades along the $5 \mathrm{Cs}$, 4Rs, themes, system level, and DRM cycle breakdowns. Each group of sources is weighted equally, i.e. for the capital categorization, which has five capitals; $20 \%(100 / 5)$ of the final grade goes to each capital group. Similarly, within each group sources are also weighted equally. It has been structured this way because some groups have more sources than others. There is currently no empirical evidence to support a larger weight for any sources over others, although part of this study is to explore this question. Depending on the results of the analysis of all resilience measurement data being collected through the testing process, different weights or weighting approaches may be incorporated in the future.

In the event of a flood, a similar process is undertaken to collect the data for the 29 outcome indicators. Again the data can be collected using any of the five data collection methods (for example, household survey). However, in this case assigning an A-D grade is too premature. For example, there is no way to tell how many deaths are acceptable to warrant an A vs. C grade. Instead the raw data will be collected and the assessor will be asked on a scale of A-D what is his or her professional perception of the level of resilience, where $\mathrm{A}$ is perceived to be an excellent or resilient outcome and $\mathrm{D}$ is a bad or not resilient outcome. Over time these perceptions matched with the raw data may allow for deeper insight into what actual flood resilience looks like for communities.

\subsection{What the measurement framework does well and what it does not do}

Frankenberger et al. (2014) argue that "[a]lthough ample lip service is often given to conducting comprehensive analy- 
sis, many NGOs rely heavily on participatory rural appraisal methods. Such reliance on qualitative data means they miss out on capturing important contextual information that is often available through secondary sources". They further point out that NGOs tend to focus data collection on areas most directly related to their theory of change. One key benefit of our framework and tool is that it encourages NGOs to look beyond the aspects they have traditionally focused on and to search out a broader variety of information sources.

Frankenberger et al. (2014) also note that NGO programming is often constrained by the rigidity of donor requirements. There exists a strong preference for "visible" programming such as flood protection infrastructure or humanitarian food distribution; less visible, or socially focused, programming is less desirable because it is more difficult to quantify. At the same time, disaster resilience programming is challenging because building disaster resilience requires an integrated approach which crosses many traditional sectoral or thematic boundaries such as education, market access, and environmental stewardship. We propose that one of the key benefits of a measurement framework such as this one is that once validated it may assist NGOs to analyse and then show how different aspects of their community development work collectively contribute to building flood resilience. It may also allow for long-term incremental change to be shown within a short funding cycle time frame.

By making a distinction between community level and enabling environment sources of resilience, using the measurement tool has the potential to crystallize the focus of advocacy work. Sources of resilience which are designated community level are possibly more effectively targeted by community-level action. Enabling environment designated sources, in contrast, may be the target of higher-level stakeholder engagement or advocacy towards authorities.

As Levine (2014) argues, thresholds pose a significant problem to resilience measurement frameworks such as this one. For many sources of resilience, it may be that they are not at all useful until they have reached a certain level, which corrupts the grading approach. Our approach to this valid critique is to emphasize that we are not purporting to be presenting the definitive community flood resilience measure; rather, we are collecting information which will enable us to empirically analyse community flood resilience. An exploration of whether thresholds exist in sources of resilience, when it comes to whether they impact outcomes, will be a key focus of that analysis.

Many scholars (Levine, 2014; Mitchell, 2013; Béné et al., 2012) have highlighted the at-times uneasy relationship between resilience and vulnerability. Measuring resilience should in no way replace a vulnerability analysis. Our framework is designed to work alongside rather than replace vulnerability and capacity assessments or any other analysis and engagement processes. Indeed, we encourage the use of existing data gathering processes to collect data for measuring the sources and outcomes.

\section{From framework to tool}

To test the framework at scale and collect the data required for undertaking empirical analysis of community flood resilience, this framework was implemented into a community flood resilience measurement tool - an integrated, hybrid web-based and mobile device system for creating questionnaires based on the flexible combination of data collection methods for each source, assigning data collection work, collecting data, undertaking grading, generating outputs, and storing data on a (protected) central database. The six NGOs implementing the tool have been trained in understanding the framework and using the tool. Over 2 years they will collect baseline, end line, and outcome measures (if a flood occurs) in 75 communities in eight countries. A train-the-trainer workshop was conducted with approximately 20 NGO staff from 9 to 13 November 2015. During this week the staff were trained to (a) implement the tool and (b) train their colleagues to implement the tool.

Implementing the tool includes being confident in ones understanding of the rationale behind the tool, being able to consistently grade sources, interpret outputs, and use the internet and mobile applications. It also critically requires a sound understanding of how the tool outputs should, and should not, be utilized. The measurement tool does not replace existing processes, but it does foster an open dialogue around findings. It is designed to help identify potential areas for intervention, but choosing an intervention is a much more complex process which must consider multiple factors and perspectives.

As with all information, the implementing NGO is obliged to feed information back to the community in an accessible and responsible manner. While the final decision rests with the NGO, we strongly advise against feeding back information on quantitative scoring because of the specialist training required to accurately interpret grades. Grades on their own are largely meaningless; what is important for analysis and communities is how different sources interact and how resilience is changing over time in that community. Pilot testing to date has shown that the information gleaned from the measurement process, presented in a qualitative way, can provide a very useful starting point for discussions with communities about flood resilience.

Internal communication must also be carefully considered. There is the risk that the generation of a grade may result in competition between project managers or field workers. It is up to the core assessment team to contextualize the measurement process and resulting grades within the wider context of their community development work to ensure that the grades are understood. There may be a temptation to gravitate towards interventions which one believes will increase the resilience grade with the least amount of resources or effort. While one of the benefits of the tool is that it might identify relatively cost-effective "quick wins", it should never be 
the case that the objective of the intervention becomes the increase of the resilience grade per se.

For the purpose of the empirical research, all data which go into the tool system are effectively anonymized. All respondents provide informed consent before information is collected, and no individual can be identified from the data (either in its raw form or aggregated).

\section{Conclusion and way forward}

Schipper and Langston's (2015) review and expert consultation report argue that measurement frameworks are "based on assumptions about how systems work, albeit informed assumptions" (p. 19). Measurement frameworks make assumptions about the way in which the presence or absence of each indicator (often measured ex ante) will impact resilience ex post. If this project is to achieve its aim of empirically exploring the critical sources of resilience, we need to do more than just measure sources in a number of communities; we need to test those measures against outcomes. This is why we are collecting post-flood outcome data - so that the original sources can be compared to outcomes in order to understand what really made a difference in the flood event and recovery (i.e. actual resilience).

The implementation of the measurement tool described above will generate an unprecedented database of community-level information and experience with flooding, collected in a consistent way. Data will be augmented by information from implementing NGOs regarding the community context, major events, or changes in the community during the study period, and interventions implemented. Analysis of these data will lead to insights about community flood resilience generally: what typical community profiles, patterns in strengths and weaknesses across the different categorizations, correlations between different capacities, and effectiveness of different intervention types are.

Our analysis of the validity of the sources of resilience within the framework - our hypothesis from research to-date - will take a multi-pronged approach. Firstly, we will explore the empirical relationship between the sources (recorded in the baseline) and outcomes (recorded in the post-flood outcome measurement). A suite of quantitative data analysis methods will be used to undertake this endeavour. Furthermore, each time a source is graded ( 75 communities at baseline and end line), assessors are asked two question about the source:

1. Were you confident grading this source? (Y/N)

2. Is this source relevant to assess resilience to flooding? $(\mathrm{Y} / \mathrm{N})$

In this way we are collecting quantitative information on the perspective of the practitioners working with flood prone communities on each of the 88 sources of resilience. This quantitative information is then complemented by anonymous structured feedback and anonymous in-depth semistructured interviews and focus group discussions with implementers throughout the process. This feedback process will also explore how the process and results of the measurement tool are informing decision-making on interventions.

Preliminary implementer feedback at the time of writing has indicated that the process of training staff to use the tool, and implementing the tool, is already producing positive outcomes. In particular, implementing NGOs have reported that the holistic view of the community system is building local staff capacity to think systemically about their work. For example, in addition to the traditional physical infrastructure, the human and social elements required to make an early warning system operational are being considered early. The data collection effort holds many co-benefits for supporting other NGO work beyond a flood focus. The data collection technology is considered superior in its accuracy and efficiency to traditional paper-based approaches.

NGOs implementing the measurement tool have expressed a desire for a more explicit handling of power, indicating a preference for a sixth "political capital" to be added to the five capitals framework. Similarly they have indicated the need for more explicit incorporation of social inclusion/exclusion in the measurement framework. These are all recommendations which should be considered carefully by the field as it move forward.

Via this process we hope to be able to generate evidence for which of the sources of resilience, if any, make a difference across diverse contexts. It is possible that community flood resilience is entirely contextually specific, or it boils down to a few core sources of resilience meeting a certain threshold; this is what we will explore. The extensive testing phase is also providing a platform for the formation of a peer group of practitioners working on community flood resilience and using the measurement tool. The insights this peer group generates together provide a critical feedback to resilience measurement and practice, as well as builds practitioner capacity. In the future reflection on this extensive process will allow critical reflection on many of the challenges associated with measuring resilience.

Winderl (2014) concludes his comprehensive review of measurement frameworks with a set of recommendations or lessons, presumably for the development of future frameworks or iterations of existing ones. These recommendations are theoretically sound but would be impractical to implement within one framework. When working in such an applied field, and relying on collaboration from communities, NGOs and other non-research institutions, there is little space for idealism in research design. Our endeavour to date has highlighted that capacity and willingness to implement complex theoretical frameworks are very limited at the grassroots NGO level. There is a need to appreciate that staff resources and budgets are very limited, and implementing idealistic frameworks in a time-consuming manner will distract from 
any interactions and bringing tangible benefits to the communities. We are also keenly aware that communities are not there as research test beds to study whether resilience can be observed; rather, testing frameworks need to bring a benefit to the communities working with NGOs and researchers.

The measurement framework presented here is by no means perfect; the design team sacrificed a number of "niceto-haves" in order to design a framework and tool which is both functional and analytically useful. We found that designing the framework and tool in an alliance between practitioners, academics, and risk engineers has contributed to optimizing it within practical constraints. Our long-term vision is to develop a replicable and scalable approach to measuring community flood resilience. The approach described here could also be adjusted to apply to different perils and different levels of social organization. By utilizing a consistent framework, information on resilience is comparable and insights can more readily be identified. 


\section{Appendix A: Additional literature which informed the development of the Zurich Flood Resilience Measurement Framework}

In addition to the documents cited in the article, the working group also reviewed and drew insight from the following sources:

Adger, W., Huges, T., Folke, C., Carpenter, S., and Rockstöm, J.: Social-Ecological Resilience to Coastal Disasters, Science, 309, 1036-1039, 2005.

Aerts, J. C. J. H., Botzen, W. J. W., Emanuel, K., Lin, N., de Moel, H., and Michel-Kerjan, E. O.: Evaluating flood resilience strategies for coastal megacities, Science, 344, 473-475, doi:10.1126/science.1248222, 2014.

Ainuddin, S. and Routray, J. K.: Earthquake hazards and community resilience in Baluchistan, Nat. Hazards, 63, 909-937, 2012.

American Red Cross: Community resilience Assessment Tool, Household and committee surveys for measuring overall community resilience and for tracking changes following Red Cross integrated interventions ("Ritaline"), http://preparecenter.org/sites/default/files/ritaline_ presentation_v2014_02.pdf (last access: January 2017), 2013.

Australian Bureau of Statistics: Measuring Social Capital. An Australian Framework and Indicators, Information paper 1378.0, Canberra, 2004.

Australian Red Cross:Relationships matter: the application of social capital to disaster resilience, National Disaster Resilience Roundtable report, Melbourne, Australia, 2013.

Briguglio, L., Cordina, G., Farrugia, N., and Vella, S.: Economic vulnerability and resilience concepts and measurements, Research Paper/UNU-WIDER, No. 2008.55, UNU-WIDER, Helsinki, 2005.

Bruneau, M., Chang, S. E., Eguchi, R. T., Lee, G. C., Rourke, T. D., Reinhorn, A. M., Shinozuka, M., Tierney, K., Wallace, W., and Von Winterfeldt, D.: A framework to quantitatively assess and enhance the seismic resilience of communities, Earthq. Spectra, 19, 733-752, 2003.

Burton, C. G.: The development of metrics for community resilience to natural disasters., PhD 3523093, University of South Carolina, South Carolina, 2012.

Cabell, J. and Oelofse, M.: An indicator framework for assessing agroecosystem resilience, Ecol. Soc., 17, 18, 2012. Cannon, T. and Muller-Mahn, D.:Vulnerability, resilience and development discourses in context of climate change, Nat. Hazards, 55, 621-635, 2010.

Cumming, G., Barnes, G., Perz, S., Schmink, M., Sieving, K., Southworth, J., Binford, M., Holt, R., Stickler, C., and Van Holt, T.: An exploratory framework for the empirical measurement of resilience, Ecosystems, 8, 975-987, 2005.

Cutter, L. S., Barnes, L., Berry, M., Burton, C., Evans, E., Tate, E., and Webb, J.: Community and regional resilience to natural disasters: perspective from hazards, disasters and emergency management, CARRI research report 1 , Community and Regional Resilience Institute, Oak Ridge, 2008a.

Cutter, L. S., Barnes, L., Berry, M., Burton, C., Evans, E., Tate, E., and Webb, J.: A place-based model for understanding community resilience to natural disasters, Global Environ. Change, 18, 598-606, 2008 b.

Hills, T., Pramova, E., Neufeldt, H., Ericksen, P., Thornton, P., Noble, A., Weight, E., Campbell, B., and McCartney, M.: A Monitoring Instrument for Resilience, CCAFS Working Paper no. 96, CGIAR Research Program on Climate Change, Agriculture and Food Security (CCAFS), Copenhagen, Denmark, 2015.

ICE: Flooding: Engineering Resilience, report from the Institution of Civil Engineers, 15 pp., http://test2.ice.org.uk/ getattachment/6fb6807f-6e90-4780-b463-1ad88a2d3837/

SEE-SoNIT1 \textemdashFlooding.aspx (last access: 24 January 2017), 2008.

IFRC: Of networks, norms, and trust. The role of social capital in reinforcing community resilience, Geneva, 2012.

IFRC: Asia-Pacific Input Document for the post2015 Framework for Disaster Risk Reduction (HFA2) - Key Area 1 - Building Community Resilience, http://web.archive.org/web/20160329061902/http: //6thamcdrr-thailand.net/6thamcdrr/Portals/0/KA1_Final_ Hi_301014-2.pdf (last access: 24 January 2017), 2014.

Jones, L., Ludi, E., and Levine, S.: Towards a characterisation of adaptive capacity: a framework analysing adaptive capacity at the local level, ODI Background Notes, December 2010, Overseas Development Institute, London, 2010.

Jonkman, S. and Kelman, I.: An analysis of the causes and circumstances of flood disaster deaths, Disaster, 29, 75-97, 2005.

Kurosaki, T. and Khan, H.: Floods, Relief Aid, and Household Resilience in Rural Pakistan: Findings from a Pilot Survey in Khyber Pakhtunkhwa, Rev. Agrar. Stud., 2, 79-107, 2011.

Low, B., Ostrom, E., Simon, C., and Wilson, J.: Redundancy and diversity: do they influence optimal management?, in: Navigating social-ecological systems: building resilience for complexity and change, edited by: Berkes, F., Colding, J., and Folke, C., Cambridge University Press, Cambridge, 83-114, 2003.

Low, S. and Kim, L.:The Role of Social Capital in Strengthening Disaster Resilience in Thailand, prepared for the Southeast Asia Regional Delegation (SEARD), International Federation of Red Cross and Red Crescent Societies (IFRC) and the Thailand Red Cross Society (TRCS), Bangkok, 2014.

Mayunga, J. S.: Understanding and applying the concept of community disaster resilience: a capital-based approach, A draft working paper prepared for social vulnerability and resilience building, Munich, Germany, 1-16, 2007.

Norris, F. H., Stevens, S. P., Pfefferbaum, B., Wyche, K. F., and Pfefferbaum, R. L.: Community resilience as a 
metaphor, theory, set of capacities and strategy for disaster readiness, Commun. Psychol., 41, 127-150, 2008.

Olsson, P., Folke, C., and Berkes, F.: Adaptive comanagement for building resilience in social-ecological systems, Environ. Manage., 34, 75-90, 2004.

Rose, A.: Economic Resilience to natural and man-made disasters: Multidisciplinary origins and contextual dimensions, Environ. Hazards, 7, 383-398, 2007.

Simonovic, S. P. and Peck, A.: Dynamic Resilience to Climate Change Caused Natural Disasters in Coastal Megacities: Quantification Framework, British J. Environ. Clim. Change, 3, 378-401, 2013.

Torrens Resilience Institute: Developing a model and tool to measure community disaster resilience, Community Disaster Resilience Scorecard Toolkit, Adelaide, 2012.
Twigger-Ross, C., Kashefi, E., Weldon, S., Brooks, K., Deeming, H., Forrest, S., Fielding, J., Gomersall, A., Harries, T., McCarthy, S., Orr, P., Parker, D., and Tapsell, S.: Flood Resilience Community Pathfinder Evaluation: Rapid Evidence Assessment, Defra, London, 2014.

UN: Targets and Indicators For Addressing Disaster Risk Management in the Post-2015 Development Agenda, UNDP Learning Resources Center, 18-19 July 2013, New York, 2013.

van Kien, N.: Social Capital, Livelihood Diversification and Household Resilience to Annual Flood Events in Vietnamese Mekong River Delta, EEPSEA Research Report No. 2011RR10, Economy and Environment Program for Southeast Asia (EEPSEA), Singapore, 2011.

WaterAid: Disasters framework, WaterAid, London, UK, 2013. 
Appendix B: Sources of resilience and post-flood

measures

Table B1. The 88 sources of resilience grouped by capital, showing other categorization tags.

\begin{tabular}{|c|c|c|c|c|}
\hline Name & Theme & Context & DRM cycle & $4 \mathrm{Rs}$ \\
\hline \multicolumn{5}{|c|}{ Financial capital sources of resilience } \\
\hline $\begin{array}{l}\text { (Inter-)National disaster response } \\
\text { budget }\end{array}$ & Education & $\begin{array}{l}\text { Enabling } \\
\text { environment }\end{array}$ & Reconstruction & Rapidity \\
\hline Business flood insurance & Life and health & Community level & Coping & Rapidity \\
\hline Communal social safety net & Life and health & Community level & Coping & Rapidity \\
\hline Household flood Insurance & Life and health & Community level & Coping & Rapidity \\
\hline Business credit access & Life and health & Community level & Coping & Redundancy \\
\hline Household credit access & Life and health & Community level & Coping & Redundancy \\
\hline Income and affordability & Life and health & Community level & Coping & Resourcefulness \\
\hline Continuity of business & Life and health & Community level & $\begin{array}{l}\text { Crisis } \\
\text { preparedness }\end{array}$ & Rapidity \\
\hline Household budget management & Life and health & Community level & $\begin{array}{l}\text { Crisis } \\
\text { preparedness }\end{array}$ & Resourcefulness \\
\hline Household income continuity strategy & Life and health & Community level & $\begin{array}{l}\text { Crisis } \\
\text { preparedness }\end{array}$ & Resourcefulness \\
\hline $\begin{array}{l}\text { Household financial savings that } \\
\text { protect long-term assets }\end{array}$ & Life and health & Community level & $\begin{array}{l}\text { Prospective risk } \\
\text { reduction }\end{array}$ & Robustness \\
\hline $\begin{array}{l}\text { Social safety net (legislative, national } \\
\text { schemes) }\end{array}$ & Life and health & $\begin{array}{l}\text { Enabling } \\
\text { environment }\end{array}$ & Coping & Redundancy \\
\hline Functioning financial market & Life and health & $\begin{array}{l}\text { Enabling } \\
\text { environment }\end{array}$ & Coping & Resourcefulness \\
\hline $\begin{array}{l}\text { Government appropriations for } \\
\text { infrastructure maintenance }\end{array}$ & Life and health & $\begin{array}{l}\text { Enabling } \\
\text { environment }\end{array}$ & $\begin{array}{l}\text { Corrective risk } \\
\text { reduction }\end{array}$ & Robustness \\
\hline $\begin{array}{l}\text { Community development investment } \\
\text { vehicles }\end{array}$ & Life and health & $\begin{array}{l}\text { Enabling } \\
\text { environment }\end{array}$ & $\begin{array}{l}\text { Prospective risk } \\
\text { reduction }\end{array}$ & Resourcefulness \\
\hline Conservation budget & Life and health & $\begin{array}{l}\text { Enabling } \\
\text { environment }\end{array}$ & $\begin{array}{l}\text { Prospective risk } \\
\text { reduction }\end{array}$ & Robustness \\
\hline $\begin{array}{l}\text { Mitigation financing (provided } \\
\text { through public or private) }\end{array}$ & Life and health & $\begin{array}{l}\text { Enabling } \\
\text { environment }\end{array}$ & $\begin{array}{l}\text { Prospective risk } \\
\text { reduction }\end{array}$ & Robustness \\
\hline \multicolumn{5}{|c|}{ Human capital sources of resilience } \\
\hline $\begin{array}{l}\text { Non-erosive flood recovery } \\
\text { knowledge }\end{array}$ & $\begin{array}{l}\text { Assets and } \\
\text { livelihoods }\end{array}$ & Community level & Coping & Robustness \\
\hline Flood water control knowledge & $\begin{array}{l}\text { Assets and } \\
\text { livelihoods }\end{array}$ & Community level & $\begin{array}{l}\text { Corrective risk } \\
\text { reduction }\end{array}$ & Resourcefulness \\
\hline $\begin{array}{l}\text { Flood vulnerability perception and } \\
\text { management knowledge }\end{array}$ & $\begin{array}{l}\text { Assets and } \\
\text { livelihoods }\end{array}$ & Community level & $\begin{array}{l}\text { Corrective risk } \\
\text { reduction }\end{array}$ & Robustness \\
\hline $\begin{array}{l}\text { Flood exposure management } \\
\text { knowledge }\end{array}$ & $\begin{array}{l}\text { Assets and } \\
\text { livelihoods }\end{array}$ & Community level & $\begin{array}{l}\text { Prospective risk } \\
\text { reduction }\end{array}$ & Robustness \\
\hline Flood exposure perception & $\begin{array}{l}\text { Assets and } \\
\text { livelihoods }\end{array}$ & Community level & $\begin{array}{l}\text { Prospective risk } \\
\text { reduction }\end{array}$ & Robustness \\
\hline Understanding of future flood risk & $\begin{array}{l}\text { Assets and } \\
\text { livelihoods }\end{array}$ & Community level & $\begin{array}{l}\text { Prospective risk } \\
\text { reduction }\end{array}$ & Robustness \\
\hline Value of education & Education & Community level & Coping & Resourcefulness \\
\hline Educational attainment & Education & $\begin{array}{l}\text { Enabling } \\
\text { environment }\end{array}$ & $\begin{array}{l}\text { Prospective risk } \\
\text { reduction }\end{array}$ & Resourcefulness \\
\hline Political awareness & Governance & Community level & $\begin{array}{l}\text { Corrective risk } \\
\text { reduction }\end{array}$ & Resourcefulness \\
\hline Personal safety & Life and health & Community level & Coping & Resourcefulness \\
\hline First aid knowledge & Life and health & Community level & $\begin{array}{l}\text { Crisis } \\
\text { preparedness }\end{array}$ & Robustness \\
\hline
\end{tabular}


Table B1. Continued.

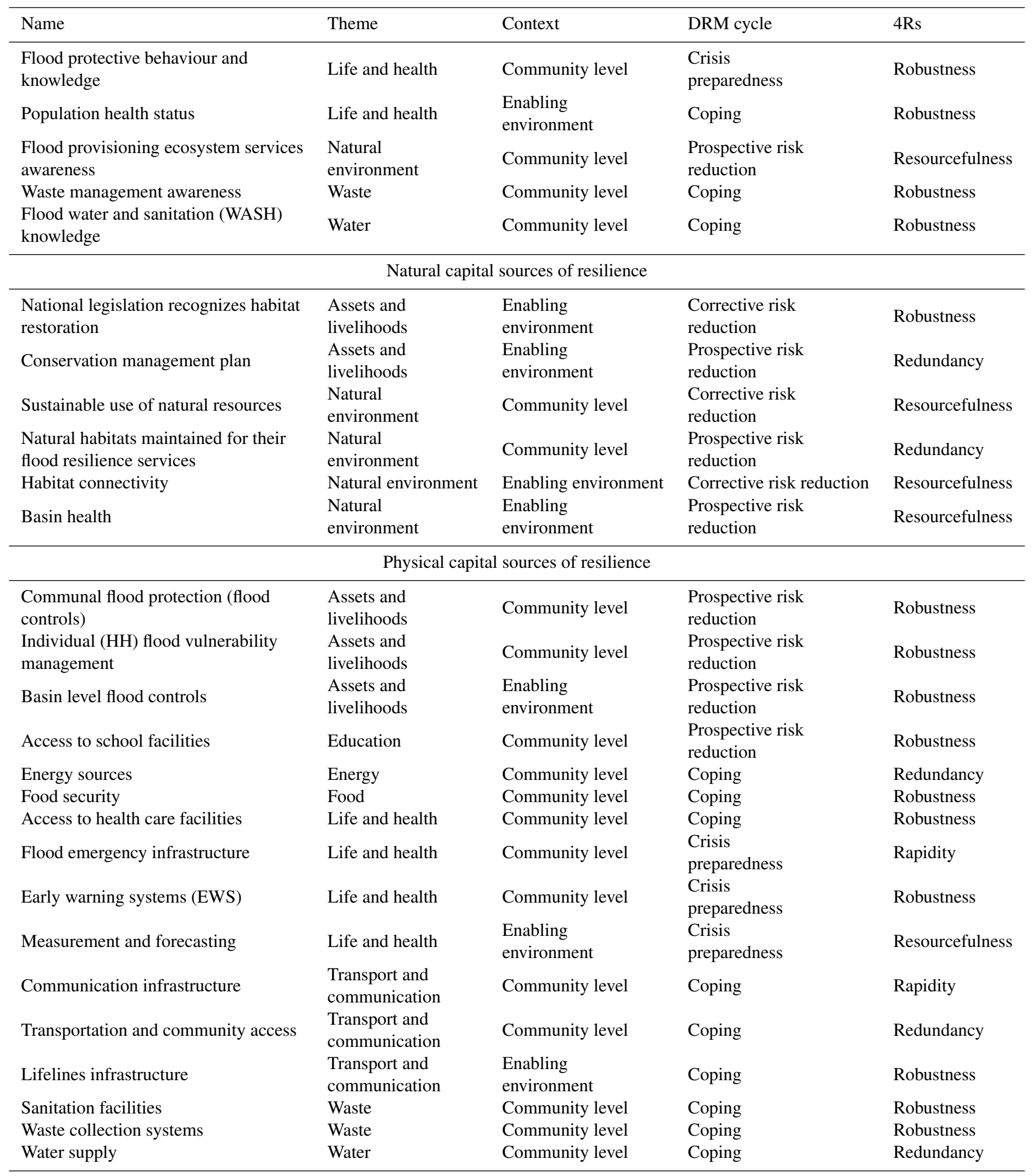


Table B1. Continued.

\begin{tabular}{|c|c|c|c|c|}
\hline Name & Theme & Context & DRM cycle & $4 \mathrm{Rs}$ \\
\hline \multicolumn{5}{|c|}{ Social capital sources of resilience } \\
\hline $\begin{array}{l}\text { Mutual assistance systems and safety } \\
\text { nets }\end{array}$ & $\begin{array}{l}\text { Assets and } \\
\text { livelihoods }\end{array}$ & Community level & Coping & Resourcefulness \\
\hline Social norms and security of assets & $\begin{array}{l}\text { Assets and } \\
\text { livelihoods }\end{array}$ & Community level & Coping & Robustness \\
\hline $\begin{array}{l}\text { Strategy to maintain or quickly resume } \\
\text { schooling interrupted by flooding }\end{array}$ & Education & Community level & Coping & Rapidity \\
\hline $\begin{array}{l}\text { Functioning and equitable education } \\
\text { system }\end{array}$ & Education & Community level & Coping & Robustness \\
\hline $\begin{array}{l}\text { Strategy to maintain or quickly resume } \\
\text { local energy supply in the event of a } \\
\text { flood }\end{array}$ & Energy & Community level & Coping & Rapidity \\
\hline $\begin{array}{l}\text { Appropriate and equitable access to } \\
\text { energy }\end{array}$ & Energy & Community level & Coping & Robustness \\
\hline $\begin{array}{l}\text { Strategy to maintain or quickly resume } \\
\text { provision of local food supplies in the } \\
\text { event of a flood }\end{array}$ & Food & Community level & Coping & Rapidity \\
\hline $\begin{array}{l}\text { Functioning and equitable food supply } \\
\text { systems }\end{array}$ & Food & Community level & Coping & Robustness \\
\hline $\begin{array}{l}\text { National policy and plan for forecasting } \\
\text { ability }\end{array}$ & Governance & Community level & Coping & Rapidity \\
\hline Village or District Flood Plan & Governance & Community level & Coping & Rapidity \\
\hline $\begin{array}{l}\text { Community representative } \\
\text { bodies/structures for flood } \\
\text { management coordination }\end{array}$ & Governance & Community level & Coping & Resourcefulness \\
\hline $\begin{array}{l}\text { Coordination mechanism across } \\
\text { communities }\end{array}$ & Governance & Community level & Coping & Resourcefulness \\
\hline $\begin{array}{l}\text { Culture for community information } \\
\text { sharing }\end{array}$ & Governance & Community level & Coping & Resourcefulness \\
\hline Social inclusiveness & Governance & Community level & Coping & Resourcefulness \\
\hline Social leadership & Governance & Community level & Coping & Resourcefulness \\
\hline $\begin{array}{l}\text { Flood regulation and local } \\
\text { enforcement }\end{array}$ & Governance & Community level & Coping & Robustness \\
\hline $\begin{array}{l}\text { Government policies and planning and } \\
\text { mainstreaming of flood risk }\end{array}$ & Governance & Community level & Coping & Robustness \\
\hline $\begin{array}{l}\text { Watershed/basin-scale management } \\
\text { plan and structure }\end{array}$ & Governance & $\begin{array}{l}\text { Enabling } \\
\text { environment }\end{array}$ & Coping & Resourcefulness \\
\hline $\begin{array}{l}\text { Strategy to maintain or quickly resume } \\
\text { health care services interrupted by } \\
\text { flooding }\end{array}$ & Life and health & Community level & Coping & Rapidity \\
\hline $\begin{array}{l}\text { Formal community emergency } \\
\text { services integrate flood advice and } \\
\text { management }\end{array}$ & Life and health & Community level & Coping & Resourcefulness \\
\hline $\begin{array}{l}\text { Social participation in flood } \\
\text { management-related activities }\end{array}$ & Life and health & Community level & Coping & Resourcefulness \\
\hline $\begin{array}{l}\text { Strategies for the delivery of } \\
\text { actionable information for flood } \\
\text { management }\end{array}$ & Life and health & Community level & Coping & Resourcefulness \\
\hline $\begin{array}{l}\text { Functioning and equitable health } \\
\text { system }\end{array}$ & Life and health & Community level & Coping & Robustness \\
\hline Social norms and personal security & Life and health & Community level & Coping & Robustness \\
\hline $\begin{array}{l}\text { Access to external, formal flood } \\
\text {-related services }\end{array}$ & Life and health & Community level & Reconstruction & Resourcefulness \\
\hline $\begin{array}{l}\text { National environment conservation } \\
\text { legislation }\end{array}$ & $\begin{array}{l}\text { Natural } \\
\text { environment }\end{array}$ & Community level & Coping & Resourcefulness \\
\hline
\end{tabular}


Table B1. Continued.

\begin{tabular}{lllll}
\hline Name & Theme & Context & DRM cycle & 4Rs \\
\hline $\begin{array}{l}\text { Community plan for the sustainable } \\
\text { management of natural resources and } \\
\text { preservation of ecosystem services }\end{array}$ & $\begin{array}{l}\text { Natural } \\
\text { environment }\end{array}$ & Community level & $\begin{array}{l}\text { Prospective risk } \\
\text { reduction }\end{array}$ & Resourcefulness \\
$\begin{array}{l}\text { Strategy to maintain or quickly resume } \\
\text { provision of mobility services in the } \\
\text { event of a flood }\end{array}$ & $\begin{array}{l}\text { Transport and } \\
\text { communication }\end{array}$ & Community level & Coping & Rapidity \\
$\begin{array}{l}\text { Appropriate and equitable access to } \\
\text { mobility }\end{array}$ & $\begin{array}{l}\text { Transport and } \\
\text { communication }\end{array}$ & Community level & Coping & Robustness \\
$\begin{array}{l}\text { Strategy to maintain or quickly resume } \\
\text { local waste collection and disposal } \\
\text { services in the event of a flood }\end{array}$ & Waste & Community level & Coping & Rapidity \\
$\begin{array}{l}\text { Functioning and equitable waste } \\
\text { collection \& disposal services }\end{array}$ & Waste & Community level & Coping & Robustness \\
$\begin{array}{l}\text { Strategy to maintain or quickly resume } \\
\text { provision of local safe water in the } \\
\text { event of a flood }\end{array}$ & Water & Community level & Coping & Rapidity \\
$\begin{array}{l}\text { Functioning and equitable water } \\
\text { services }\end{array}$ & Water & Community level & Coping & Robustness \\
\hline
\end{tabular}


Table B2. The 29 ex post outcome measures, showing variable type and other categorization tags.

\begin{tabular}{|c|c|c|c|}
\hline Outcome measure & $\begin{array}{l}\text { Variable } \\
\text { type }\end{array}$ & Theme & Context \\
\hline Death and injury due to flooding & Impact & Life and health & Community level \\
\hline Building losses and damage & Impact & Assets and livelihoods & Community level \\
\hline Property losses and damage & Impact & Assets and livelihoods & Community level \\
\hline Prevalence of post-flood illness & Impact & Life and health & Community level \\
\hline Health care provision & Impact & Life and health & Community level \\
\hline Education provision & Impact & Education & Community level \\
\hline Income stability & Impact & Assets and livelihoods & Community level \\
\hline Business interruption & Impact & Assets and livelihoods & Community level \\
\hline Food security & Impact & Food & Community level \\
\hline Communications infrastructure & Impact & Transport and communications & Enabling environment \\
\hline Road and transportation infrastructure & Impact & Transport and communications & Enabling environment \\
\hline Clean water & Impact & Water & Community level \\
\hline Sanitation & Impact & Waste & Community level \\
\hline Waste disposal & Impact & Waste & Community level \\
\hline Electricity & Impact & Energy & Enabling environment \\
\hline Social cohesion & Impact & Governance & Community level \\
\hline Property crime and looting & Impact & Governance & Community level \\
\hline Natural environment & Impact & Natural environment & Enabling environment \\
\hline Flood learning & Impact & Governance & Community level \\
\hline Early warning system function & Action & Governance & Enabling environment \\
\hline Preparatory actions & Action & Life and health & Community level \\
\hline External flood assistance & Action & Governance & Enabling environment \\
\hline Legal and regulatory constraints & Action & Governance & Enabling environment \\
\hline Selling assets & Action & Assets and livelihoods & Community level \\
\hline Risky livelihoods & Action & Assets and livelihoods & Community level \\
\hline Insurance & Action & Assets and livelihoods & Community level \\
\hline Flood frequency and severity & Control & $\mathrm{n} / \mathrm{a}$ & Enabling environment \\
\hline Number of people impacted & Control & $\mathrm{n} / \mathrm{a}$ & Community level \\
\hline Flood duration & Control & $\mathrm{n} / \mathrm{a}$ & Enabling environment \\
\hline
\end{tabular}




\section{Appendix C: Example source of resilience}

As an illustrative example, we present one of the 88 sources of resilience, fully specified.

The source is named "access to school facilities".

The categorizations are as follows:

- capital group: physical

- 4Rs: robustness

- level: community level

- DRM cycle: prospective risk reduction

- theme: education.

The source is explained to the assessor with the following description and instructions: "This aspect of the education theme considers the adequacy of the infrastructure to support provision of education and how it stands up in flood situations - schooling is an important aspect of daily life". Both the interruption itself and the lost education time lead to problems (children at home instead of daily rhythm at school). Schooling during floods should obviously be conducted only where and when it is safe to do so depending on the flood scenario. For flash flood situations, rapidity and robustness are key and schooling should resume as soon as possible. For long-standing, large-scale standing water flood situations, it is important that schooling can continue, such as in alternate locations or safe locations.
Data may be collected via household survey questions, community consultation discussion topics/questions, key informant interviews, interest group discussion topics/questions, or third-party sources, as appropriate to context determined by the implementing NGO. For the example source the data collection options are shown in the table below ${ }^{3}$.

The "access to school facilities" source of resilience is graded $\mathrm{A}$ to $\mathrm{D}$ with the following guidance:

- A: school facility (or location where formal school setting takes place) is built robust, located away from flood zone, and accessible through safe and protected ways even during and after floods; schooling continues to take place.

- B: school facility is impacted by flooding but maintains sufficient basic staffing and equipment to provide care, or school may be impacted but informal schooling is planned to go on in a safe place during and after floods.

- C: school facility is impacted and cannot avoid significant lost school curriculum or, while informal schooling may be available, it is unplanned or inconvenient and leads to significant lost school curriculum.

- D: no schooling facility, or school prone to damage rendering it in-operational during flood, or school not accessible during flood for either teachers or students.

\footnotetext{
${ }^{3}$ It should be noted that while this example source allows mostly dichotomous answers for all data source options, allowed answers vary from yes/no to other response lists, and free form entry.
} 
Table C1. Data collection questions and answer options for source "access to school facilities".

Household survey question
Household survey

answer options

Does school take place during and after flood events? (this may be due to damage to the school or 1 - Yes

the way to get to school, but also because the school is needed for emergency shelter) 2 - No

Has the school facility been damaged during the last floods so it could not operate anymore? 1 - Yes

$2-$ No

$1-$ Yes

Can schools be reached during and after floods safely by staff and students?

$2-$ No

Community question

Community allowed

answers

Does school take place during and after flood events? (this may be due to damage to the school or 1 - Yes

the way to get to school, but also because the school is needed for emergency shelter) 2 - No

Has the school facility been damaged during the last floods so it could not operate anymore? 1 - Yes

$2-\mathrm{No}$

$1-$ All

Can all reach the school facility during flooding?

2 - Some

3 - None

Key informant question

Key informant

allowed answers

Ask e.g. the principal: locate school facility or where schooling/teaching takes place on a map - 1 - Yes

do schools get affected during floods? Do schools get used as emergency shelter and thus $\quad 2-$ No

schooling is interrupted?

Has the school facility been damaged during the last floods so it could not operate anymore?

$1-$ Yes

$2-\mathrm{No}$

$1-$ All

Can all reach the school facility during flooding?

2 - Some

3 - None

Interest group question

Interest group

allowed answers

Ask the teachers group: locate school facility or where schooling/teaching takes place on a

$1-$ Yes

map - do schools get affected during floods? Do schools get used as emergency shelter and thus

$2-\mathrm{No}$

schooling is interrupted?

Has the school facility been damaged during the last floods so it could not operate anymore?

1 - Yes

$2-\mathrm{No}$

$1-$ All

2-Some

3 - None

Third-party source question

Third-party source

allowed answers

Locate school facility or where schooling/teaching takes place on a map - do schools get affected

during floods? Do schools get used as emergency shelter and thus schooling is interrupted?

$1-$ Yes

$2-\mathrm{No}$

Has the school facility been damaged during the last floods so it could not operate anymore?

$1-$ Yes

$2-\mathrm{No}$

$1-$ All

2 - Some

Can all reach the school facility during flooding? 
Edited by: S. Fuchs

Reviewed by: two anonymous referees

\section{References}

ADB - Asian Development Bank: Investing in resilience: Ensuring a disaster-resistant future, Asian Development Bank, Manila, 2013.

Adger, N., Hughes, T., Folke, C., Carpenter, S., and Rockström, J.: Social-Ecological Resilience to Coastal Disasters, Science, 309, 1036-1039, 2005.

Alinovi, L., Mane, E., and Romano, D.: Measuring Household Resilience to Food Insecurity: Application to Palestinian Households, EC-FAO Food Security Programme, Working Paper, http://citeseerx.ist.psu.edu/viewdoc/download?doi=10.1. 1.175.7411\&rep=rep1\&type=pdf (last access: 24 January 2017), 2009.

Bahadur, A., Peters, K., Wilkinson, E., Pichon, F., Gray, K., and Tanner, T.: The 3As: Tracking Resilience Across Braced, BRACED Knowledge Manager working paper, Overseas Development Institute, London, 2015.

Béné, C., Godfrey Wood, R., Newsham, A., and Davies, M.: Resilience: new utopia or new tyranny? Reflection about the potentials and limits of the concept of resilience in relation to vulnerability reduction programmes, Institute of Development Studies, Brighton, 2012.

Berkes, F. and Ross, H.: Community resilience: toward an integrated approach, Soc. Nat. Resour., 26, 5-20, 2013.

Bruneau, M.: Enhancing the Resilience of Communities Against Extreme Events from an Earthquake Engineering Perspective, J. Secur. Educ., 1, 159-167, doi:10.1300/J460v01n04_14, 2006.

Carpenter, S., Walker, B., Anderies, J. M., and Abel, N.: From Metaphor to Measurement: Resilience of What to What?, Ecosystems, 4, 765-781, 2001.

Carpenter, S., Westley, F., and Turner, M.: Surrogates for Resilience of Social-Ecological Systems, Ecosystems, 8, 941-944, 2005.

Cimellaro, G., Reinhyorn, A., and Bruneau, M.: Seismic resilience of a hospital system, Struct. Infrastruct. Eng., 6, 127-144, 2010.

Constas, M. and Barrett, C. B.: Principles of Resilience Measurement for Food Insecurity: Metrics, Mechanisms, and Implementation Plans, presented at Expert Consultation on Resilience Measurement Related to Food Security sponsored by Food and Agricultural Organization and World Food Programme, 1921 February 2013, Rome, 2013.

Constas, M., Frankenberger, T., and Hoddinott, J.: Resilience Measurement Principles: Toward an Agenda for Measurement Design, Resilience Measurement Technical Working Group Technical Series 1, Food Security Information Network, Rome, 2014.

Constas, M., Frankenberger, T., Klaus, D., and Mock, M.: Qualitative Data and Subjective Indicators for Resilience Measurement, Resilience Measurement Technical Working Group, Technical Series No. 4, Food Security Information Network, Rome, 2015.

Cutter, S., Burton, C., and Emrich, C.: Disaster resilience indicators for benchmarking baseline conditions, J. Homeland Secur., 7, 51, doi:10.2202/1547-7355.1732, 2010.

de Sherbinin, A., Reuben, A. Levy, M., and Johnson, L.: How Environmental Indicators Are Being Used in Policy and Management Context, Center for International Earth Science Informa- tion Network, Yale and Columbia Universities, New Haven and New York, 2013.

DFID: Sustainable Livelihoods Guidance Sheets, Department of International Development, UK, http://www.eldis.org/vfile/upload/ 1/document/0901/section2.pdf (last access: 24 January 2017), 1999.

DFID: Defining Disaster Resilience: A DFID Approach Paper, UK Department for International Development, London, 2011.

Frankenberger, T. and Nelson, S.: Background Paper for the Expert Consultation on Resilience Measurement for Food Security, Paper presented at Expert Consultation on Resilience Measurement Related to Food Security, 19-21 February 2013, Rome, 2013.

Frankenberger, T., Constas, M. A., Nelson, S., and Starr, L.: Resilience programing among nongovernmental organizations: Lessons for policy makers, Food Policy Report, International Food Policy Research Institute, Washington, D.C., 2014.

Heltberg, R., Hossain, N., and Reva, A. (Eds.): Living Through Crises: How the Food, Fuel, and Financial Shocks Affect the Poor, World Bank, Washington, D.C., 2012.

Holling, C.: Understanding the Complexity of Economic, Ecological, and Social Systems, Ecosystems, 4, 390-405, 2001.

IFRC: Characteristics of a Safe and Resilient Community, Community Based Disaster Risk Reduction Study, ARUP International Development, International Federation of Red Cross and Red Crescent Societies, Geneva, http://www.ifrc.org/PageFiles/ 96986/Final_Characteristics_Report.pdf (last access: 24 January 2017), 2011.

IFRC: Understanding community resilience and program factors that strengthen them: A comprehensive study of Red Cross Red Crescent Societies tsunami operation, International Federation of Red Cross and Red Crescent Societies, June 2012, https://www.ifrc.org/PageFiles/96984/Final_ Synthesis_Characteristics_Lessons_Tsunami.pdf (last access: 24 January 2017), 2012.

IFRC: IFRC Framework for Community Resilience, International Federation of Red Cross and Red Crescent Societies, Geneva, http://www.ifrc.org/Global/Documents/Secretariat/201501/ 1284000-FrameworkforCommunityResilience-EN-LR.pdf (last access: 24 January 2017), 2014.

IPCC: Managing the Risks of Extreme Events and Disasters to Advance Climate Change Adaptation, in: A Special Report of Working Groups I and II of the Intergovernmental Panel on Climate Change, edited by: Field, C. B., Barros, V., Stocker, T. F., Qin, D., Dokken, D. J., Ebi, K. L., Mastrandrea, M. D., Mach, K. J., Plattner, G.-K., Allen, S. K., Tignor, M., and Midgley, P. M., 2012.

Keating, A., Campbell, K., Mechler, R., Michel-Kerjan, E., Mochizuki, J., Kunreuther, H., Bayer, J., Hanger, S., McCallum, I., See, L., Williges, K., Atreya, A., Botzen, W., Collier, B., Czajkowski, J., Hochrainer, S., and Egan, C.: Operationalizing Resilience Against Natural Disaster Risk: Opportunities, Barriers and A Way Forward, Zurich Flood Resilience Alliance, http://opim.wharton.upenn.edu/risk/library/ zurichfloodresiliencealliance_ResilienceWhitePaper_2014.pdf (last access: 24 January 2017), 2014.

Keating, A., Campbell, K., Mechler, R., Magnuszewski, P., Mochizuki, J., Liu, W., Szoenyi, M., and McQuistan, C.: Disaster resilience: What it is and how it can engender a meaningful change in development policy, Dev. Policy Rev., 35, 65-91, 2017. 
Kellett, J. and Caravani, A.: Financing disaster risk reduction: A 20year story of international aid, ODI and the Global Facility for Disaster Reduction and Recovery at the World Bank, London, Washington, 2013.

Knutsson, P. and Ostwalk, M.: A process-oriented sustainable livelihoods approach - A tool for increased understanding of vulnerability, adaptation and resilience, Mitig. Adapt. Strat. Global Change, doi:10.1007/s11027-006-4421-9, 2006.

Levine, S.: Assessing Resilience: Why Quantification Misses the Point, Humanitarian Policy Group Working Paper, ODI, London, 2014.

MCEER: Engineering resilience solutions from earthquake engineering to extreme events, Multidisciplinary Center for Earthquake Engineering Research, Buffalo, USA, 2007.

Mechler, R.: Reviewing estimates of the economic efficiency of disaster risk management: opportunities and limitations of using risk-based cost-benefit analysis, Nat. Hazards, 81, 2121-2147, 2016.

Mitchell, A.: Risk and Resilience: From Good Idea to Good Practice - A Scoping Study for the Experts Group on Risk and Resilience, Organization for Economic Co-operation and Development, Paris, 2013.

Nelson, D., Adger, W., and Brown, K.: Adaptation to environmental change: contributions of a resilience framework, Annu. Rev. Environ. Resour., 32, 395-419, 2007.

NRC - National Research Council: Disaster Resilience: A National Imperative, The National Academies Press, Washington, D.C., 2012

Oddsdottir, F., Lucas, B., and Combaz, É.: Measuring Disaster Resilience, GSDRC Helpdesk Research Report 1045, GSDRC, University of Birmingham, Birmingham, UK, 2013.

OECD: Guidelines for Resilience Systems Analysis. How to analyze risk and build a roadmap to resilience, https: //www.oecd.org/dac/ResilienceSystemsAnalysisFINAL.pdf (last access: 24 January 2017), 2014.

Ostadtaghizadeh, A., Ardalan, A., Paton, D., Jabbari, H., and Khankeh, H. R.: Community Disaster Resilience: a Systematic Review on Assessment Models and Tools, PLOS Curr. Disast., 7, doi:10.1371/currents.dis.f224ef8efbdfcf1d508dd0de4d8210ed, 2015.

Oxfam GB: A Multidimensional Approach for Measuring Resilience, Oxfam GB Working Paper, http: //oxfamilibrary.openrepository.com/oxfam/bitstream/10546/ 302641/4/dp-measuring-resilience-010813-en.pdf (last access: 24 January 2017), 2013.

Pasteur, K.: From Vulnerability to Resilience, Practical Action Publishing, Rugby, 2011.
Resilience Capacity Index: Resilience Capacity Index, University of California, Berkeley, http://brr.berkeley.edu/rci/, last access: 24 January 2017.

Schipper, E. L. F. and Langston, L.: A Comparative Overview of Resilience Measurement Frameworks: Analysing Indicators and Approaches, Overseas Development Institute Working Paper, Overseas Development Institute, London, 2015.

Schipper, L. and Pelling, M.: Disaster risk, climate change and international development: scope for, and challenges to, integration, Disasters, 30, 19-38, 2006.

Shaw, M.: Community development and the politics of community, Commun. Dev. J., 43, 24-36, 2007.

Tol, R. and Yohe, G.: Infinite Uncertainty, Forgotten Feedbacks, and Cost-Benefit Analysis of Climate Change, Climate Change, 83, 429-442, 2007.

Twigg, J.: Characteristics of a Disaster Resilient Community, http:// discovery.ucl.ac.uk/1346086/1/1346086.pdf (last access: 24 January 2017), 2009.

UNISDR: Terminology, http://www.unisdr.org/we/inform/ terminology (last access: 24 January 2017), 2009.

UNISDR: From Shared Risk to Shared Value - The Business Case for Disaster Risk Reduction, United Nations Office for Disaster Risk Reduction, Geneva, 2013.

UNISDR: Global Assessment Report on Disaster Risk Reduction - Making Development Sustainable: The Future of Disaster Risk Management, United Nations Office for Disaster Risk Reduction, Geneva, http://www.preventionweb.net/english/hyogo/gar/2015/ en/gar-pdf/GAR2015_EN.pdf (last access: 24 January 2017), 2015.

USAID: The Resilience Agenda: Measuring Resilience in USAID, http://www.usaid.gov/sites/default/files/documents/1866/ TechnicalNote_MeasuringResilienceinUSAID_June2013.pdf (last access: 24 January 2017), 2013.

Vincent, K.: Uncertainty in adaptive capacity and the importance of scale, Global Environ. Change, 17, 12-24, 2007.

Welsh, M.: Resilience and responsibility: governing uncertainty in a complex world, Geogr. J., 180, 15-26, doi:10.1111/geoj.12012, 2013.

Winderl, T.: Disaster Resilience Measurements: Stocktaking of ongoing efforts in developing systems for measuring resilience, United Nations Development Programme UNDP, http://www.fao.org/fileadmin/user_upload/drought/ docs/DisasterResilienceMeasurements.pdf (last access: 20 January 2017), 2014.

Zhou, H., Wang, J., Wan, J., and Jia, H.: Resilience to natural hazards: a geographic perspective, Nat. Hazards, 53, 21-41, 2010. 